Research Article

\title{
Skull shape and size variation within and between mendocinus and torquatus groups in the genus Ctenomys (Rodentia: Ctenomyidae) in chromosomal polymorphism context
}

\author{
Rodrigo Fornel ${ }^{1,2}$, Pedro Cordeiro-Estrela ${ }^{1,3}$ and Thales Renato O. de Freitas ${ }^{1,4}$ \\ ${ }^{1}$ Departamento de Genética, Universidade Federal do Rio Grande do Sul, Porto Alegre, RS, Brazil. \\ ${ }^{2}$ Universidade Regional Integrada do Alto Uruguai e das Missões - Campus de Erechim, Erechim, RS, \\ Brazil. \\ ${ }^{3}$ Departamento de Sistemática e Ecologia, Centro de Ciências Exatas e da Natureza - Campus I, \\ Universidade Federal da Paraíba, João Pessoa, PB, Brazil. \\ ${ }^{4}$ Programa de Pós-Graduação em Genética e Biologia Molecular, Universidade Federal \\ do Rio Grande do Sul, Porto Alegre, RS, Brazil.
}

\begin{abstract}
We tested the association between chromosomal polymorphism and skull shape and size variation in two groups of the subterranean rodent Ctenomys. The hypothesis is based on the premise that chromosomal rearrangements in small populations, as it occurs in Ctenomys, produce reproductive isolation and allow the independent diversification of populations. The mendocinus group has species with low chromosomal diploid number variation $(2 n=46-48)$, while species from the torquatus group have a higher karyotype variation $(2 n=42-70)$. We analyzed the shape and size variation of skull and mandible by a geometric morphometric approach, with univariate and multivariate statistical analysis in 12 species from mendocinus and torquatus groups of the genus Ctenomys. We used 763 adult skulls in dorsal, ventral, and lateral views, and 515 mandibles in lateral view and 93 landmarks in four views. Although we expected more phenotypic variation in the torquatus than the mendocinus group, our results rejected the hypothesis of an association between chromosomal polymorphism and skull shape and size variation. Moreover, the torquatus group did not show more variation than mendocinus. Habitat heterogeneity associated to biomechanical constraints and other factors like geography, phylogeny, and demography, may affect skull morphological evolution in Ctenomys.
\end{abstract}

Keywords: Cranium, geometric morphometrics, phenotypic evolution, subterranean rodent.

Received: May 6, 2017; Accepted: November 23, 2017.

\section{Introduction}

The genus Ctenomys is composed of approximately 70 species that are found in South America (Bidau, 2015; Freitas, 2016). These subterranean rodents show the largest chromosomal polymorphism among mammals, with diploid numbers varying from $2 \mathrm{n}=10$ in C. steinbach $i$ to $2 \mathrm{n}=70$ in C. pearsoni (Reig et al., 1990; Ortells and Barrantes, 1994). Because of this large karyotype variation, chromosomal speciation has been proposed as a probable, or primary mechanism of cladogenesis within the genus Ctenomys (King, 1993; Ortells and Barrantes, 1994). Adaptive radiation caused by key innovations to the underground niche (Nevo, 1979) and patchy population structure (Reig

Send correspondence to Thales Renato O. de Freitas. Departamento de Genética, Universidade Federal do Rio Grande do Sul, Avenida Bento Gonçalves 9500, 91501-970 Porto Alegre, RS, Brazil. E-mail: thales.freitas@ufrgs.br. et al., 1990) have been proposed as alternative or concurrent mechanisms to explain high rates of diversification. However, most of these mechanisms have been seriously challenged by analyses based on molecular data. The mere fact that Ctenomys presents high rates of diversification has failed to receive significant support when compared to Hystricognathous sister lineages (Cook and Lessa, 1998). Tomasco and Lessa (2007) have shown that chromosomal populations are polyphyletic relative to mitochondrial DNA in C. pearsoni. Adding to this fact, no sign of negative heterosis has been found in hybrid zones of Ctenomys (Freitas, 1997; Gava and Freitas, 2002, 2003). Negative heterosis would be required in traditional models of chromosomal speciation to disrupt gene flow between populations. Thus, its absence seriously undermines these traditional models as a primary mechanism of diversification in Ctenomys. However, Navarro and Barton (2003) and Rieseberg and Livingstone (2003) have proposed that the 
reduced recombination of rearranged chromosomes might favor the accumulation of adaptive differences on rearranged regions. In this article, we analyze an adaptive structure, the skull, within two clades of Ctenomys that differ radically in number of chromosomal rearrangements.

Studies based on morphological, cytogenetic, and molecular data have proposed different lineages or main groups within the genus Ctenomys (Lessa and Cook, 1998; Contreras and Bidau, 1999; D'Elia et al., 1999; Mascheretti et al., 2000; Slamovits et al., 2001; Parada et al., 2011). Two of these groups, mendocinus and torquatus, are very different in chromosomal polymorphism.

The mendocinus group, suggested by Massarini et al. (1991), is known for its low variation in chromosomal diploid number. The majority of species have from $2 n=46$ to $2 \mathrm{n}=48$, the exception being $C$. rionegrensis with $2 \mathrm{n}=48-56$ (Reig et al., 1992). This group is formed by seven species: C. mendocinus $(2 \mathrm{n}=47-48), C$. azarae $(2 \mathrm{n}=46-48)$, C. chasiquensis $(2 \mathrm{n}=47-48), C$. rionegrensis $(2 \mathrm{n}=48-56), C$. porteousi $(2 \mathrm{n}=47-48)$, C. australis $(2 \mathrm{n}=48)$, and C. flamarioni $(2 \mathrm{n}=48)$ (Massarini et al., 1991; Reig et al., 1992; Freitas, 1994; Massarini et al., 1998; D’Elia et al., 1999; Massarini and Freitas, 2005). All species from this group present the asymmetric sperm form (Vitullo et al., 1988; Freitas, 1994, 1995; Massarini et al., 1998). The mendocinus group is found in centralwestern Argentina, western Uruguay, and in the coastal plain of southern Brazil (Massarini et al., 1991, Massarini and Freitas, 2005) (Figure 1).

The torquatus group, proposed by Parada et al. (2011), shows a high chromosomal diploid number variation, from $2 \mathrm{n}=40$ to $2 \mathrm{n}=70$. It is formed by $C$. torquatus with 2n=40-46 (Freitas and Lessa, 1984; Fernandes et al., 2009a,b), C. lami with 2n=54-58 (Freitas, 2001, 2007), $C$. minutus with $2 \mathrm{n}=42-50$ (Freitas, 2006), C. perrensi with 2n=50-58 (Ortells et al., 1990, Reig et al., 1992), C. pearsoni with $2 \mathrm{n}=56-70$ (Novello and Altuna, 2002), C. roigi with $2 \mathrm{n}=48$ (Ortells et al., 1990), and C. ibicuiensis with $2 \mathrm{n}=50$ (Freitas et al., 2012). All species from this group present symmetric sperm form (Vitullo et al., 1988; Freitas, 1995). The torquatus group occurs in Northern and Southern Uruguay, Southern Brazil, and Northeastern Argentina (Freitas, 1994, 2006; Parada et al., 2011) (Figure 1).

Both groups occupy heterogeneous habitats, from dunes in the Atlantic coast to low valleys in the West (Reig et al., 1990) (Figure 1). Molecular phylogenetic analyses support the mendocinus and torquatus groups as two monophyletic clades (D'Elia et al., 1999; Castillo et al., 2005; Parada et al., 2011). Contreras and Bidau (1999) proposed that chromosomal rearrangements could play an important role in the source of reproductive isolation in small populations (common in several species of genus Ctenomys). Thus, if chromosomal rearrangements act in reproductive isolation and allow populations to evolve independently of each other (by natural selection or genetic drift), we expected that the torquatus group, which has high chromosomal polymorphism, would show more variable skull shapes and sizes than the mendocinus group, which has low chromosomal polymorphism.

Geometric morphometrics is more efficient in capturing information related to the shape of the organisms and presents a greater statistical robustness than traditional measurements. In addition, it allows for the reconstruction

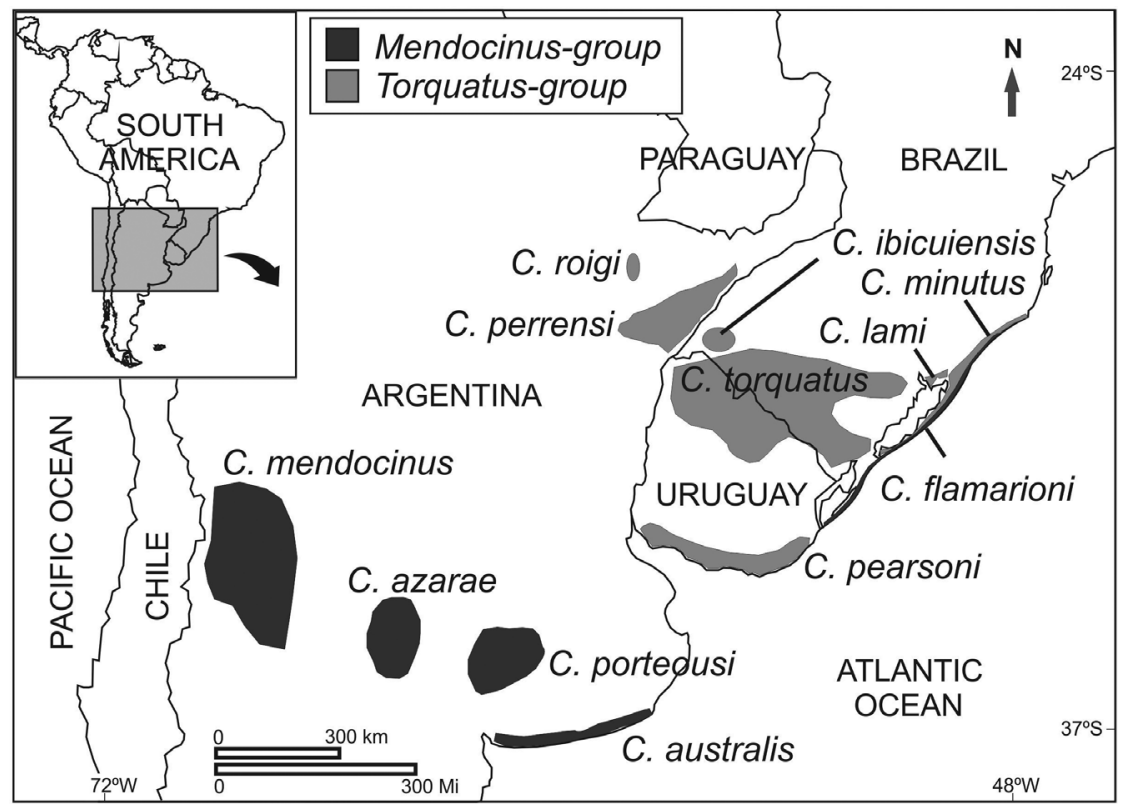

Figure 1 - Map with distribution of 12 Ctenomys species belonging to the mendocinus and torquatus groups, with the exception of $C$. rionegrensis and $C$. chasiquensis. Mendocinus-group in black: C. flamarioni $(2 \mathrm{n}=48)$, C. australis $(2 \mathrm{n}=48)$, C. porteousi $(2 \mathrm{n}=47-48)$, C. azarae $(2 \mathrm{n}=46-48)$, and $C$. mendocinus $(2 \mathrm{n}=47-48)$. Torquatus-group in grey: $C$. minutus $(2 \mathrm{n}=42-50)$, C. lami $(2 \mathrm{n}=54-58)$, C. torquatus $(2 \mathrm{n}=40-46), C$. pearsoni $(2 \mathrm{n}=56-70), C$. perrensi $(2 \mathrm{n}=50-58)$, C. ibicueisis $(2 \mathrm{n}=50)$ and $C$. roigi $(2 \mathrm{n}=48)$. 
of changes in shape and statistical inference, which is very important for the visualization of shape differences (Rohlf and Marcus, 1993). Some studies used the geometric morphometric approach to investigate the relationship between chromosomal polymorphism and morphological skull variation in Ctenomys at an intraspecific level (Fernandes et al., 2009a; Fornel et al., 2010). Therefore, at the interspecific level (among species) there is a lack of information on the role of chromosomal rearrangements in morphological evolution of Ctenomys.

Much controversy remains on the role of chromosomal diploid number variation related to speciation in the genus Ctenomys. Therefore, the aim of this study was to investigate the variation in skull shape and size within and between the mendocinus and torquatus groups and test the association of chromosomal polymorphism and skull morphological variation in these two groups.

\section{Material and Methods}

\section{Sample}

We analyzed 763 skulls and 515 mandibles of adults representing 12 species from the mendocinus and torquatus groups (Table 1). The skulls and mandibles were obtained from the following museums and scientific collections: Departamento de Genética, Universidade Federal do Rio Grande do Sul, Porto Alegre, Brazil (UFRGS); Museo Nacional de História Natural y Antropología, Montevideo, Uruguay (MUNHINA); Museo Argentino de Ciencias Naturales "Bernardino Rivadavia", Buenos Aires, Argentina (MACN); Museo de La Plata, La Plata, Argentina (MLP); Museo de Ciencias Naturales "Lorenzo Scaglia", Mar del Plata, Argentina (MMP); Museum of Vertebrate Zoology, University of California, Berkeley, USA (MVZ); American Museum of Natural History, New York, USA (AMNH); and Field Museum of Natural History, Chicago, USA

Table 1 - Sample size of skulls and mandibles of 12 species of Ctenomys from mendocinus and torquatus groups.

\begin{tabular}{llcc}
\hline Species & Group & $\mathrm{N}_{\text {Skull }}$ & $\mathrm{N}_{\text {Mandible }}$ \\
\hline C. australis (aus) & mendocinus & 31 & 27 \\
C. azarae (aza) & mendocinus & 29 & 26 \\
C. flamarioni (fla) & mendocinus & 32 & 22 \\
C. porteousi (por) & mendocinus & 30 & 28 \\
C. mendocinus (men) & mendocinus & 24 & 14 \\
C. ibicuiensis (ibi) & torquatus & 16 & 10 \\
C. lami (lam) & torquatus & 89 & 66 \\
C. minutus (min) & torquatus & 197 & 122 \\
C. pearsoni (pea) & torquatus & 77 & 60 \\
C. perrensi (per) & torquatus & 9 & 9 \\
C. roigi (roi) & torquatus & 7 & 7 \\
C. torquatus (tor) & torquatus & 222 & 124 \\
Total & & 763 & 515 \\
\hline
\end{tabular}

(FMNH). We assumed that sexual dimorphism was negligible for the present study. Interspecific differences are in general greater than sexual differences, so we used males and females together in all analyses.

\section{Geometric morphometrics}

Each cranium was photographed in the dorsal, ventral, and left lateral views of the skull and on the left side of the mandible with a digital camera, at a resolution of 3.1 megapixels $(2048 \times 1536)$, using the macro function without flash. We used 29 two-dimensional landmarks for dorsal, 30 for ventral, and 21 for lateral views of the skull, as proposed by Fernandes et al. (2009a), though Fornel et al. (2010) added another 13 landmarks for the lateral view of the mandible (Figure 2; Supplementary Table S1). Ana-

A

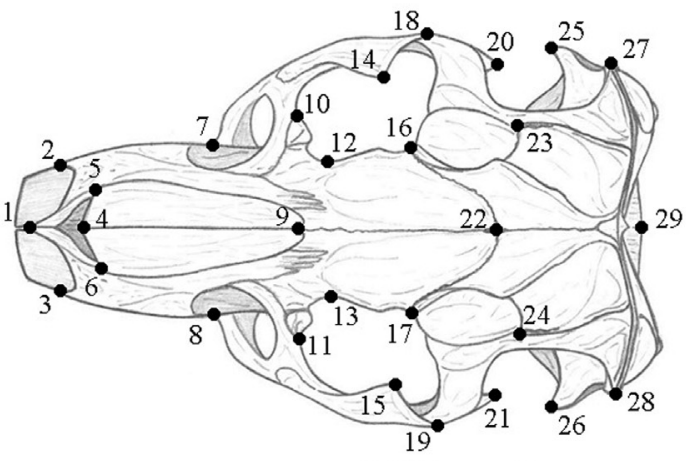

B
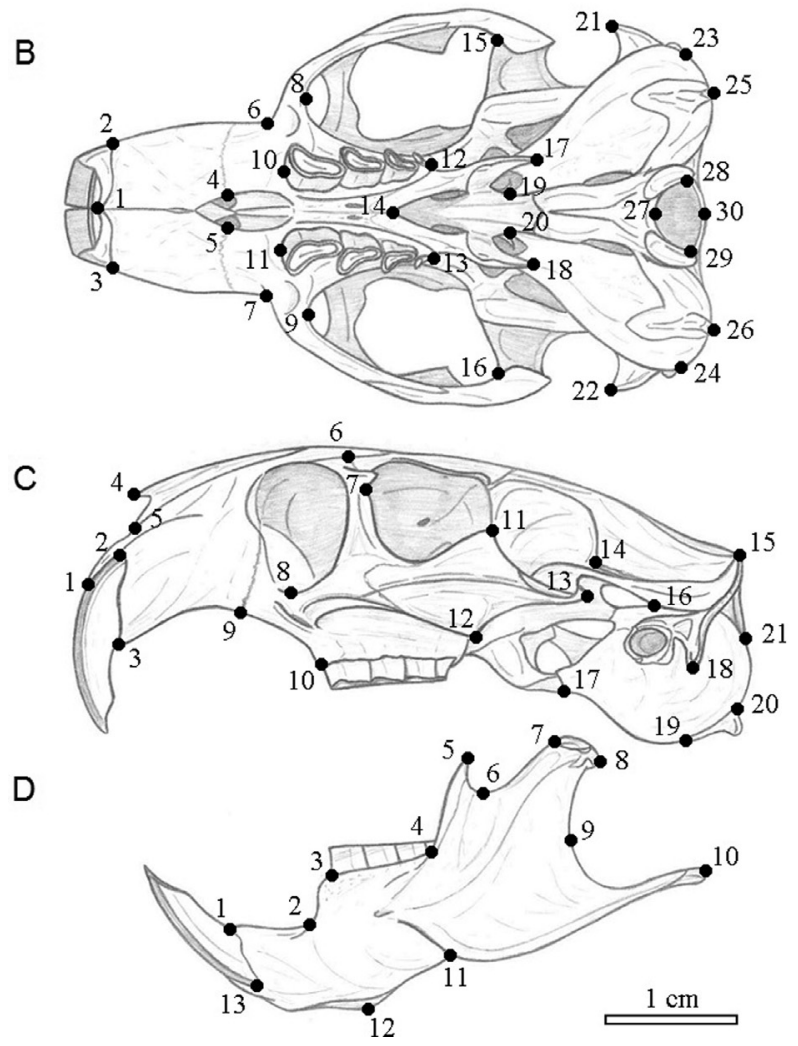

Figure 2 - Landmarks location on skull of Ctenomys for dorsal (A), ventral (B), and lateral (C) views of the cranium and lateral view of the mandible (D). See Table S1 for anatomical description of each landmark. 
tomical landmarks were positioned for each specimen using TPSDig version 1.40 software (Rohlf, 2004). All landmarks were captured by the same person (R.F.). Coordinates were superimposed using a generalized Procrustes analysis (GPA) algorithm (Dryden and Mardia, 1998), since GPA removes differences unrelated to the shape, such as scale, position, and orientation (Rohlf and Slice, 1990; Rohlf and Marcus, 1993; Bookstein, 1996a, 1996b; Adams et al., 2004). We symmetrized landmarks on both sides of the skull's dorsal and ventral views, and only the symmetric part of the variation was analyzed (Kent and Mardia, 2001; Klingenberg et al., 2002; Evin et al., 2008). The size of each skull was estimated using its centroid size, the square root of the sum of squares of the distance of each landmark from the centroid (mean of all coordinates) of the configuration (Bookstein, 1991).

\section{Statistical analysis}

For testing skull size differences we used analysis of variance (ANOVA) of the centroid size. For multiple comparisons of centroid size, we used Tukey's test and Box plots to visualize its variation. For skull shape we used principal component analysis (PCA), canonical variate analysis (CVA), and multivariate analysis of variance (MANOVA) of the principal components (PCs). To choose the number of PCs to be included in the linear discriminant analysis (LDA), we computed correct classification percentages with each combination of PCs (Baylac and Friess, 2005). We selected the subset of PCs giving the highest overall correct classification percentage. We then used a leave-one-out cross validation procedure that allows for an unbiased estimate of classification percentages (Ripley, 1996; Baylac and Friess, 2005). Cross validation is used to evaluate the performance of classification by LDA. We used LDA for computed correct classification percentages among groups and species. The Mahalanobis's $D^{2}$ distances were used to generate phenograms with the neighbor-joining method. Finally, we used Procrustes distances to measure the variation in skull shape within the mendocinus and torquatus groups, and used Levene's test to assess the equality of variances in different groups.

For all statistical analyses, as well as for generating graphs we used the $\mathrm{R}$ language and environment version 2.9.0 for Windows ( $\mathrm{R}$ Development Core Team, http://www.R-project.org) and the following libraries: MASS (Venables and Ripley, 2002), ape version 1.8-2 (Paradis et al., 2004), stats (R Development Core Team), and ade4 (Dray and Dufour, 2007). Geometric morphometric procedures were carried out using the Rmorph package, a geometric and multivariate morphometrics library for R (Baylac, 2008).

\section{Results}

\section{Size}

The two groups, mendocinus and torquatus, did not differ significantly in skull centroid size $(P>0.05)$. We found significant differences among species for size (dorsal: $F=42.94, P<0.001$; ventral: $F=39.24, P<0.001$; lateral: $F=38.96, P<0.001$; and mandible: $F=38.7, P<$ $0.001)$. However, the Tukey test showed no significant difference among species belonging to the torquatus group $(P>0.05)$ (Figure 3$)$. The species from the mendocinus group were more varied in skull centroid size than the torquatus group, with $C$. australis being significantly bigger than the other species in both groups (Tukey: $P<0.001$ in all pairwise comparisons) (Figure 3 ).

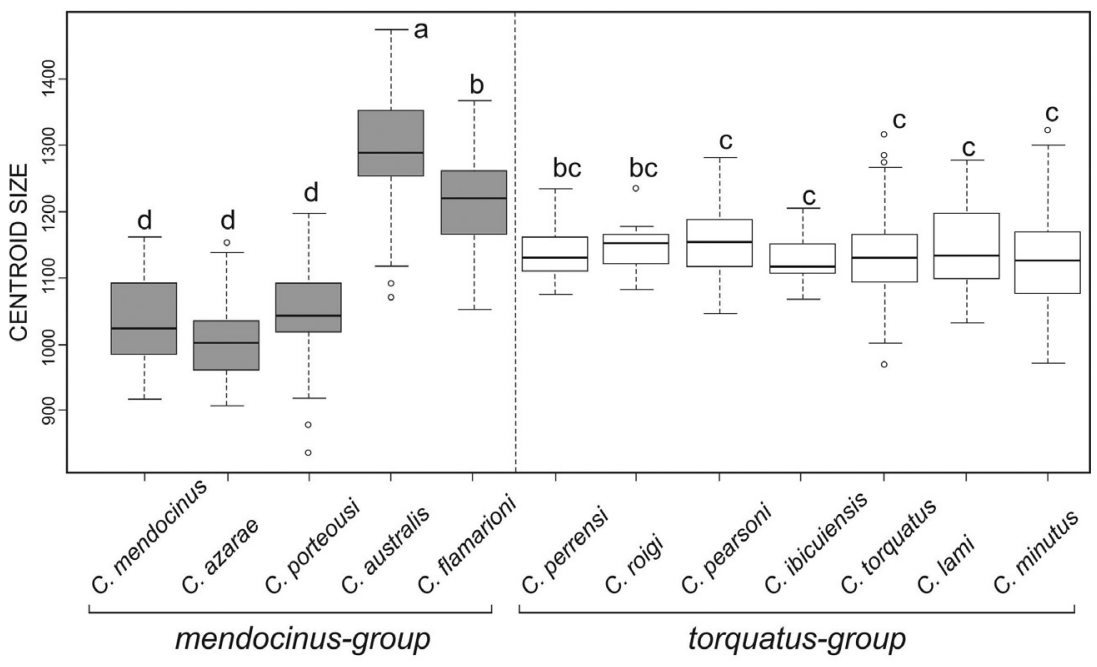

Figure 3 - Skull centroid size variability among 12 species of Ctenomys from the mendocinus and torquatus groups for dorsal view of the skull. The horizontal line represents the median, box margins are at the 25 th and 75 th percentiles, bars extend to 5 th and 95 th percentiles, and circles are outliers. Different letters above boxes represent significant differences among species for Tukey's multiple comparison tests at the $5 \%$ level. 


\section{Shape - two groups}

PCA for the three views of the cranium showed two structured groups with low superimposition corresponding to the mendocinus and torquatus groups (Figure 4A-C). Regarding the mandible, there was no difference between groups (Figure 4D). The LDA for three views of the skull and mandible showed higher percentages of correct classification for the torquatus group (Table 2). The lateral view of the skull had the highest (100\%) and the mandible the lowest (94.87\% for mendocinus and $97.16 \%$ for torquatus) percentage of correct classification in LDA (Table 2). Comparison between the two groups was significant for all views of the skull (dorsal: $\lambda_{\text {Wilks }}=0.17, F=365.4, P<$ 0.001; ventral: $\lambda_{\text {Wilks }}=0.18, F=246.68, P<0.001$; lateral: $\lambda_{\text {Wilks }}=0.21, F=555.57, P<0.001$; and mandible: $\lambda_{\text {Wilks }}=$ $0.31, F=84.22, P<0.001)$.

Skull shape differences between the two groups and among species are given in a CVA scatterplot (Figure 5). In the mendocinus group, the skull's three views provided similar results, while the torquatus group showed separation in the $1^{\text {st }}$ canonical axes (Figure 5A-C). The torquatus had a proportionally bigger rostrum, larger zygomatic arch, deeper skull, and a proportionally larger coronoid process in the mandible than the mendocinus (Figure 5A-C). The mendocinus group animals have longer nasals and a larger
Table 2 - Percentage of correct classification for mendocinus and torquatus groups using linear discriminant analysis (LDA) for dorsal, ventral, and lateral views of the skull, and lateral view of the mandible.

\begin{tabular}{lcc}
\hline & \multicolumn{2}{c}{ Group } \\
\cline { 2 - 3 } & mendocinus & torquatus \\
\hline Dorsal & 99.31 & 100 \\
Ventral & 98.63 & 100 \\
Lateral & 100 & 100 \\
Mandible & 94.87 & 97.16 \\
\hline
\end{tabular}

tympanic bulla than those of the torquatus group (Figure $5 \mathrm{~A}-\mathrm{C})$. For the mandible, CVA did not show separation between the two groups (Figure 5D).

Shape - species

There was a significant difference among species (dorsal: $\lambda_{\text {Wilks }}=0.002, F=30.41, P<0.001$; ventral: $\lambda_{\text {Wilks }}=0.002, F=32.8, P<0.001$; lateral: $\lambda_{\text {Wilks }}=0.002$, $F=33.33, P<0.001 ;$ mandible: $\lambda_{\text {Wilks }}=0.017, F=16.68$, $P<0.001)$.

The LDA for dorsal views of the skull showed the highest percentage of correct classification for C. australis, C. flamarioni, and C. roigi $(100 \%$, Table 3$)$. The species $C$. mendocinus and $C$. perrensi showed the lowest values of
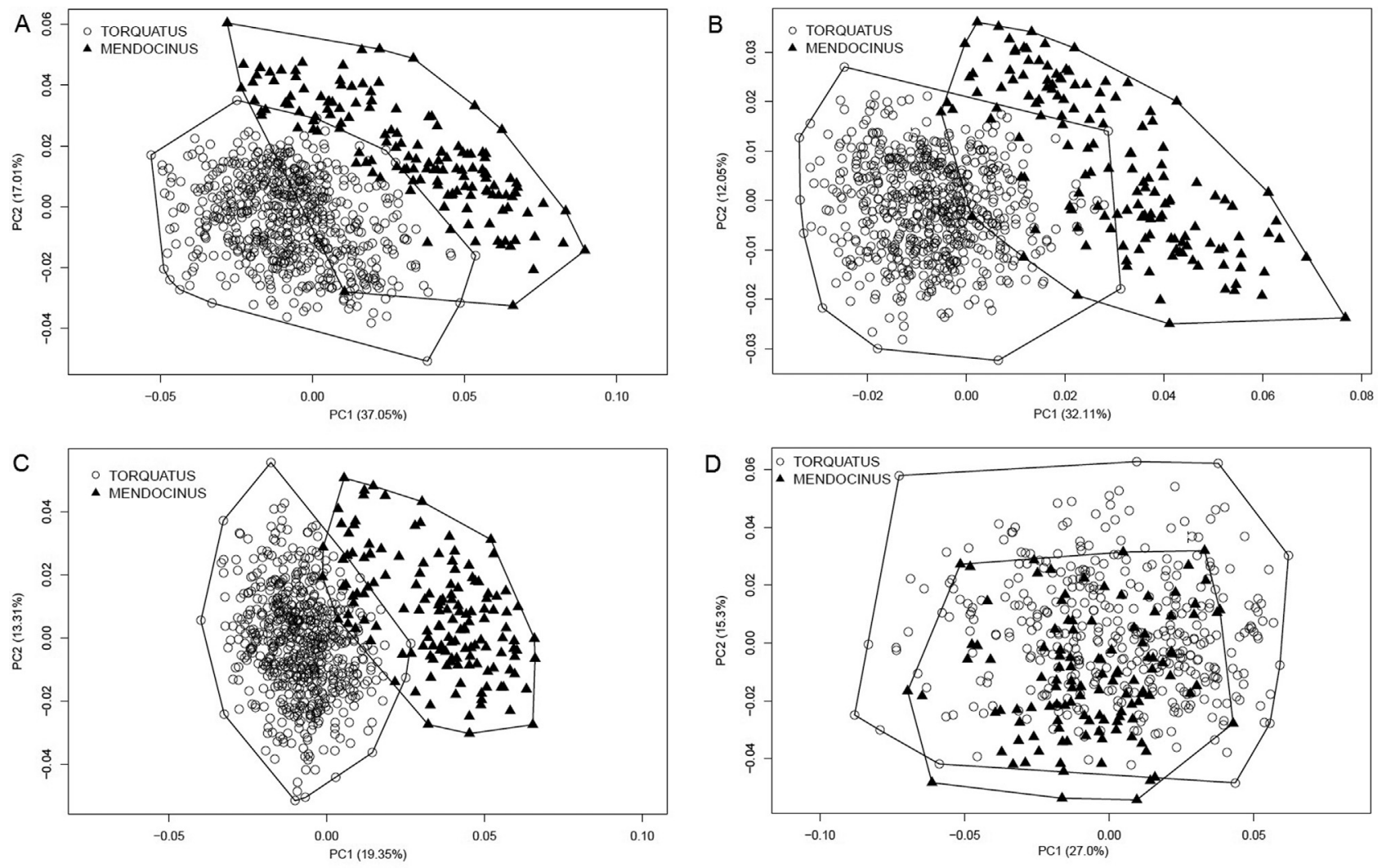

Figure 4 - Scatterplot of principal component analysis (PCA) show the two first PCs for two groups of Ctenomys, the mendocinus and torquatus groups for dorsal (A), ventral (B), and lateral (C) views of the skull and lateral view of the mandible (D). Variance percentages for PC1 and PC2 are given in parenthesis. 

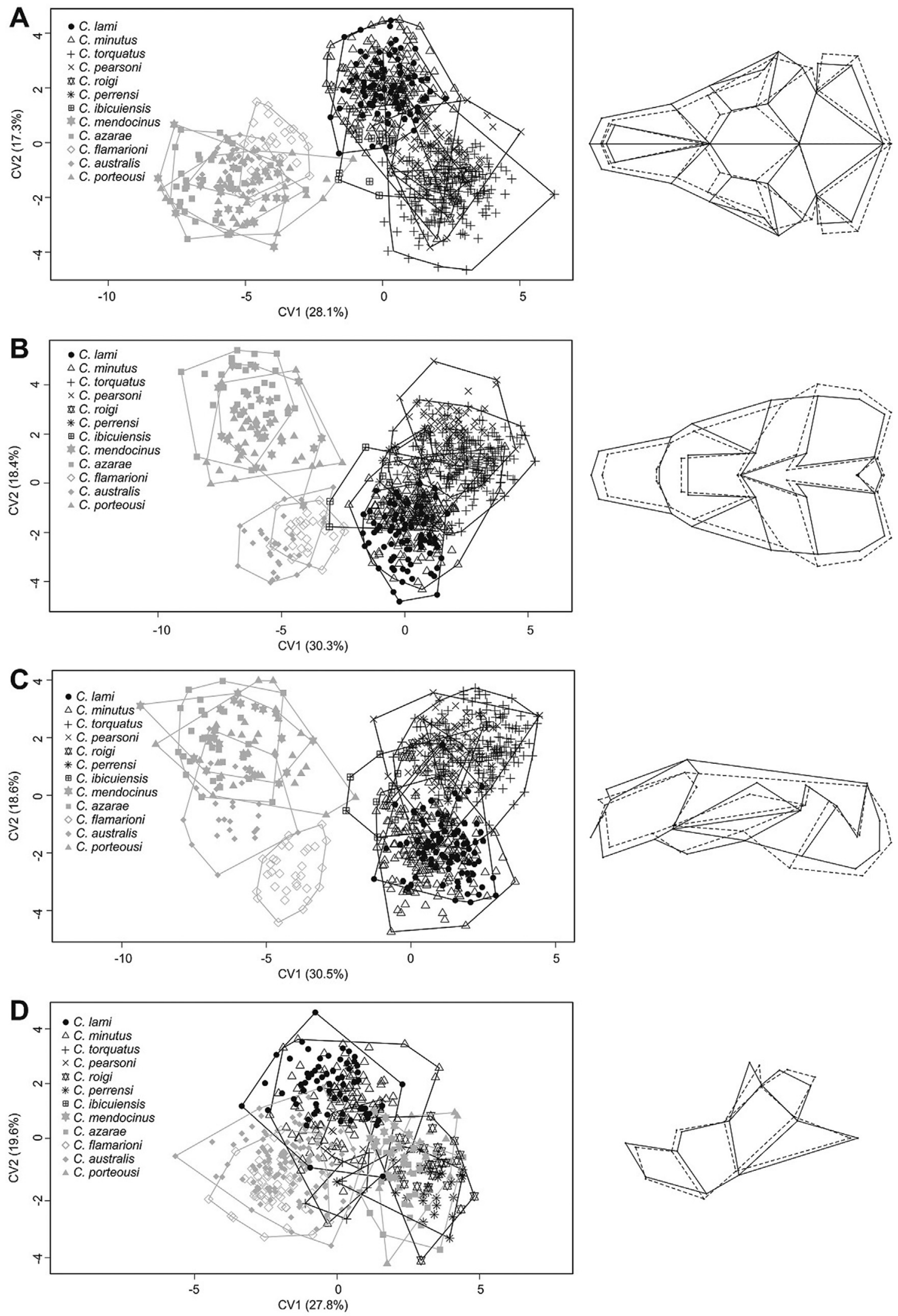

Figure 5 - Scatterplot of canonical variate analysis (CVA) show the two first canonical axis for 12 species of Ctenomys from the mendocinus and torquatus groups for dorsal (A), ventral (B), and lateral (C) views of the skull and lateral view of the mandible (D). The grids at the right side of each plot represent the differences for landmark configuration along the first $\mathrm{CV}$, where dotted lines represent the extreme negative scores and solid lines represent the extreme positive scores. Variance percentages for CV1 and CV2 are given in parenthesis. 
correct classification $(75 \%$ and $77.7 \%$, respectively, Table 3). Almost all specimens were classified in the correct group, the only exception being $C$. porteousi, which belongs to the mendocinus group and had two individuals classified erroneously in the torquatus group (Table 3 ). The other views of the skull and mandible showed lower percentages of classification than the dorsal view of the skull (data not shown).

The phenogram using morphological data for dorsal, ventral, and lateral views of the skull showed a larger separation between mendocinus and torquatus groups (Figure $6 \mathrm{~A}, \mathrm{~B}, \mathrm{D})$ than those of the mandible (Figure 6D). Moreover, the Mahalanobis distances in the cladogram indicate a subdivision in the mendocinus group, with a strong morphological association between $C$. australis and C. flamarioni, separated from C. mendocinus, C. porteousi, and C. azarae (Figure 6). In the same way, in the torquatus group, $C$. lami and $C$. minutus were strongly associated.

\section{Intragroup variation}

The variation amplitude of Procrustes distances did not differ significantly between the mendocinus and torquatus groups for dorsal, ventral, and lateral views of the skull and mandible (Levene's test: $F=0.221, P=0.64 ; F=$ $0.005, P=0.94 ; F=0.083, P=0.77 ; F=0.082, P=0.78$, respectively).

\section{Discussion}

We analyzed skull and mandible shape and size variation within and between the mendocinus and torquatus groups of the genus Ctenomys. Our results agree with other studies in determining that the two groups have very different skull morphologies. There is no evidence of convergence among species from different groups.
Contreras and Bidau (1999) suggested that chromosomal rearrangements could reduce gene flow and even promote isolation among populations. Nevertheless, some works demonstrated the occurrence of hybrid zones between different chromosomal rearrangements (Freitas, 1997; Gava and Freitas, 2002, 2003). Moreover, Fernandes et al. (2009a) found that chromosomal evolution and phenotypic variation are not necessarily related. We reject the hypothesis that a high chromosomal polymorphism is associated to a high morphological variation at the interspecific level in the mendocinu group. Our data showed that besides mendocinus and torquatus groups displaying very different chromosomal polymorphisms, there is no evidence of association between chromosomal diploid number and skull shape variation. Rieseberg and Livingstone (2003) proposed that the reduced recombination of rearranged chromosomes might favor the accumulation of adaptive differences on rearranged regions. Our data did not support this hypothesis in the genus Ctenomys, because the mendocinus group with low chromosomal polymorphism showed skull shape variation (amplitude of variation) like the torquatus group, which presented high chromosomal polymorphism. These results agree with Tomasco and Lessa (2007) who argue that chromosomal speciation might not be the main factor in Ctenomys diversification.

The mendocinus group occurs in heterogeneous habitats, from coastal dunes to the proximity of the Andes. Several species of Ctenomys are characterized as scratch (claws) and chisel-tooth (incisors) diggers. These incisors can be used for building tunnel systems, and soil hardness could influence the incisor procumbency and affect skull morphology (Vassallo, 1998; Mora et al., 2003; Verzi and Olivares, 2006). In the species of the mendocinus group we found a pattern in skull centroid size. Populations near the

Table 3 - Classification of 12 species of Ctenomys from mendocinus and torquatus groups for dorsal view of the skull using linear discriminant analysis (LDA). The diagonal line shows the samples that were correctly classified. The percentage of correct classification is given in the last line. The species abbreviations follow the same order in the first column and Table 1.

\begin{tabular}{|c|c|c|c|c|c|c|c|c|c|c|c|c|}
\hline Group & & & ndoci & & & & & & rquat & & & \\
\hline Species & aus & $a z a$ & fla & por & men & lam & $\min$ & pea & per & roi & tor & $i b i$ \\
\hline C. australis & 31 & & & & & & & & & & & \\
\hline C. azarae & & 28 & & 1 & & & & & & & & \\
\hline C. flamrioni & & & 32 & & & & & & & & & \\
\hline C. porteousi & 1 & 2 & & 24 & 1 & & 2 & & & & & \\
\hline C. mendocinus & & 2 & & & 18 & & & & & & & \\
\hline C. lami & & & & & & 78 & 11 & & & & & \\
\hline C. minutus & & & & & & 6 & 186 & 2 & & & 3 & \\
\hline C. pearsoni & & & & & & & 1 & 66 & & & 10 & \\
\hline C. perrensi & & & & & & & & & 7 & 1 & 1 & \\
\hline C. roigi & & & & & & & & & & 7 & & \\
\hline C. torquatus & & & & & & & 3 & 4 & 1 & & 214 & \\
\hline C. ibicuiensis & & & & & & & 1 & & & & 1 & 14 \\
\hline Percentage & 100 & 96.6 & 100 & 80 & 75 & 87.6 & 94.4 & 85.7 & 77.7 & 100 & 96.4 & 87.5 \\
\hline
\end{tabular}



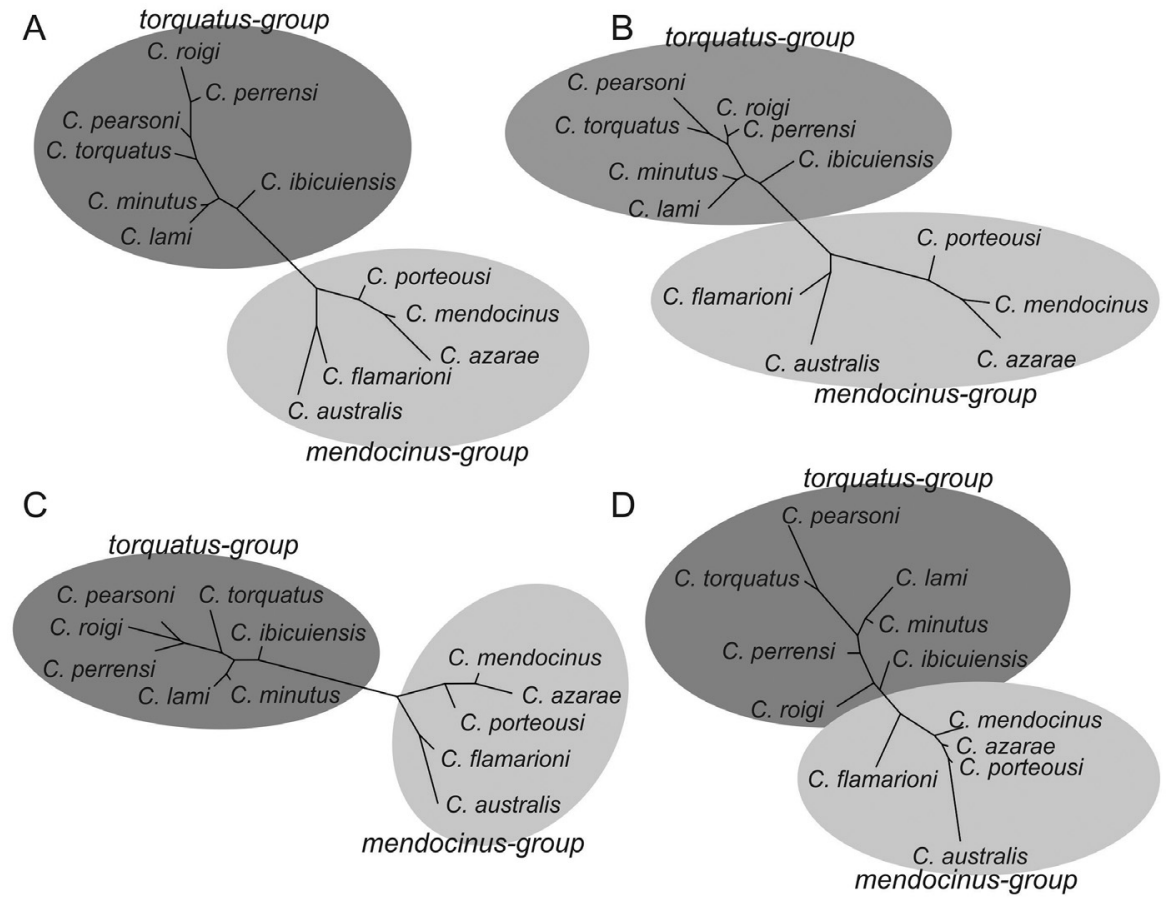

Figure 6 - Phenogram using neighbor-joining method and Mahalanobis distances from lateral view of the skull for 12 species of Ctenomys from the mendocinus and torquatus groups.

ocean coasts are bigger than those inland (see Figures 1 and 3). Thus, different types of soil hardness could play a role in biomechanical constraints and diversification in skull morphology of the Ctenomys: smaller skulls for hard soils and lager skulls for soft soils. Nevertheless, this size difference between regions could affect skull morphology due to different dietary types. Ctenomys are herbivorous and feed on a variety of grasses, eating both the subterranean and subaereal parts of gramineae (Reig et al., 1990; Lopes et al., 2015). Thus, primary productivity, food quality, and abundance may influence body size (Medina et al., 2007). Nevertheless, we do not have knowledge on the ecology of all mendocinus group species, such as data about vegetable richness, in order to completely explain the difference in skull size. The mendocinus group occupies a larger area than the torquatus group and its distribution is more fragmented (Figure 1). This more intensive isolation of the mendocinus species could allow for a larger differentiation among them. In this regard, we found a strong association between $C$. australis and C. flamarioni: both are found in the sand dunes of the Atlantic coast and are more distant from other mendocinus species (Figure 6). Thus, both ecologic and phylogenetic constraints permit $C$. australis and C. flamarioni to be very close.

Mandible shape and size were less variable than skull in the two Ctenomys groups, making for a rather weak discriminatory structure. A more confined amount of morphological variation was observed in the mandible of $C$. minutus (Fornel et al., 2010). This is probably the result of stabilizing selection, since the functions of the mandible are more restricted than in the rest of the skull (Borges et al., 2017).

Medina et al. (2007) found that the genus Ctenomys follows the converse of Bergmann's rule. This agrees with our data: larger species occupy warm areas while smaller species occupy cold and inner continent areas near the Andes mountain range. Thus, thermoregulation may not be a great constraint to subterranean species, because tunnel systems protect from the outside weather.

New studies on the association between morphological and geographical distances and on several aspects of ecological, demographic, as well as historical factors of the different Ctenomys species will help understand the evolution and the explosive cladogenesis seen in this group of rodents in Neotropical regions.

\section{Acknowledgments}

We are very grateful to Fabiano A. Fernandes, Daniza Molina-Shiller, and Gisele S. Rebelato for their help with skull photographs. We thank Michel Baylac for providing the Rmorph package. Thanks as well to all curators and collection managers who provided access to Ctenomys specimens: Enrique Gonzáles (MUNHINA); Olga B. Vacaro and Esperança A. Varela (MACN); Diego H. Verzi and A. Itatí Olivares (MLP); A. Damián Romero (MMP); James L. Patton, Eileen A. Lacey, and Christopher Conroy (MVZ); Eileen Westwig (AMNH); and Bruce D. Patterson (FMNH). This work was supported by the Conselho Nacional de Desenvolvimento Científico e Tecnológico (CNPq); 
Coordenação de Aperfeiçoamento de Pessoal de Nível Superior (CAPES); Fundação de Amparo à Pesquisa do Rio Grande do Sul (FAPERGS); Departamento de Genética UFRGS; and Projeto Tuco-tuco. P.C-E. was supported by the $\mathrm{CNPq}$ /CAPES PROTAX Program for Taxonomy. R. F. was supported by a Doctoral fellowship from CNPq (grant proc. No. 142953/2005-9).

\section{References}

Adams DC, Rohlf FJ and Slice DE (2004) Geometric morphometrics: Ten years of progress following the "revolution". Ital J Zool 71:5-16.

Baylac M and Friess M (2005) Fourier descriptors, Procrustes superimposition and data dimensionality: An example of cranial shape analysis. In: Slice DE (ed) Modern Morphometrics in Physical Anthropology. Springer-Verlag, New York, pp 145-166.

Baylac M (2008) Rmorph: A R geometric and multivariate morphometrics library. Available from the author: baylac@mnhn.fr.

Bidau CJ (2015) Family Ctenomyidae Lesson, 1842. In: Patton JL, Pardiñas UFJ and D'Elía G (eds) Mammals of South America. The University of Chicago Press, Chicago, pp 818-877.

Bookstein FL (1991) Morphometric Tools for Landmark Data: Geometry and Biology. Cambridge University Press, London, $435 \mathrm{p}$.

Bookstein FL (1996a) Biometrics, biomathematics and the morphometric synthesis. Bull Math Biol 58:313-365.

Bookstein FL (1996b) Combining the tools of geometric morphometrics. In: Marcus LF, Corti M, Loy A, Naylor G and Slice DE (eds) Advances in Morphometrics. Plenum Publishing Corporation, New York, pp 131-151.

Borges LR, Maestri R, Kubiak BB, Galiano D, Fornel R and Freitas TRO (2017) The role of soil features in shaping the bite force and related skull and mandible morphology in the subterranean rodents of genus Ctenomys (Hystricognathi: Ctenomyidae). J Zool 301:108-117.

Castillo AH, Cortinas MN and Lessa EP (2005) Rapid diversification of South American Tuco-tucos (Ctenomys: Rodentia, Ctenomyidae): Contrasting mitochondrial and nuclear intron sequences. J Mammal 86:170-179.

Contreras JR and Bidau CJ (1999) Líneas generales del panorama evolutivo de los roedores excavadores sudamericanos del género Ctenomys (Mammalia, Rodentia, Caviomorpha, Ctenomyidae). Ciencia Siglo XXI. Fundación Bartolomé Hidalgo. Buenos Aires, 123 p.

Cook JA and Lessa EP (1998) Are rates of diversification in subterranean South American tuco-tucos (genus Ctenomys, Rodentia: Octodontidae) ususlly high? Evolution 52:1521-1527.

D'Elía G, Lessa EP and Cook JA (1999) Molecular phylogeny of Tuco-tucos, genus Ctenomys (Rodentia: Octodontidae): Evaluation of the mendocinus species group and the evolution of asymmetric sperm. J Mammal Evol 6:19-38.

Dray S and Dufour AB (2007) The ade4 package: Implementing the duality diagram for ecologists. J Stat Softw 22:1-20.

Dryden IL and Mardia KV (1998) Statistical Shape Analysis. John Wiley \& Sons, New York, 347 p.
Evin A, Baylac M, Ruedi M, Mucedda M and Pons JM (2008) Taxonomy, skull diversity and evolution in a species complex of Myotis (Chiroptera: Vespertilionidae): A geometric morphometric appraisal. Biol J Linn Soc 95:529-538.

Fernandes FA, Fornel R, Cordeiro-Estrela P and Freitas TRO (2009a) Intra- and interspecific skull variation in two sister species of the subterranean genus Ctenomys (Rodentia, Ctenomyidae): coupling geometric morphometrics and chromosomal polymorphism. Zool J Linn Soc 155:220-237.

Fernandes FA, Gonçalves GL, Ximenes SSF and Freitas TRO (2009b) Karyotypic and molecular polymorphisms in Ctenomys torquatus (Rodentia: Ctenomyidae): Taxonomic considerations. Genetica 136:449-459.

Fornel R, Cordeiro-Estrela P and Freitas TRO (2010) Skull shape and size variation in Ctenomys minutus (Rodentia: Ctenomyidae) in geographical, chromosomal polymorphism, and environmental contexts. Biol J Linn Soc 101:705-720.

Freitas TRO (1994) Geographical variation of heterochromatin in Ctenomys flamarioni (Rodentia-Octodontidae) and its cytogenetic relationships with other species of the genus. Cytogenet Cell Genet 67:193-198.

Freitas TRO (1995) Geographical distribution of sperm forms in the genus Ctenomys (Rodentia Octodontidae). Rev Bras Genet 18:43-46.

Freitas TRO (1997) Chromosome polymorphism in Ctenomys minutus (Rodentia-Octodontidae). Rev Bras Genet 20:1-7.

Freitas TRO (2001) Tuco-tucos (Rodentia, Octodontidae) in southern Brazil: Ctenomys lami spec. nov. separated from $C$. minutus Nehring 1887. Stud Neotrop Fauna Environ 36:1-8.

Freitas TRO (2006) Cytogenetics status of four Ctenomys species in the south of Brazil. Genetica 126:227-235.

Freitas TRO (2007) Ctenomys lami: The highest chromosome variability in Ctenomys (Rodentia, Ctenomyidae) due to a centric fusion/fission and pericentric inversion system. Acta Theriol 52:171-180.

Freitas TRO (2016) Family Ctenomyidae (Tuco-tucos). In: Wilson DE, Lacher Jr TE and Mittermeier RA (eds) Handbook of the Mammals of the World - Volume 6, Lagomorphs and Rodents I. Lynx Edicions Publications, Barcelona, pp 1-900.

Freitas TRO and Lessa EP (1984) Cytogenetics and morphology of Ctenomys torquatus (Rodentia: Octodontidae). J Mammal 65:637-642.

Freitas TRO, Fernandes FA, Fornel R and Roratto PA (2012) An endemic new species of tuco-tuco, genus Ctenomys (Rodentia: Ctenomyidae), with a restricted geographic distribution in southern Brazil. J Mammal 93:1355-1367.

Gava A and Freitas TRO (2002) Characterization of a hybrid zone between chromosomally divergent populations of Ctenomys minutus (Rodentia, Ctenomyidae). J Mammal 83:843-851.

Gava A and Freitas TRO (2003) Inter and intra-specific hybridization in tuco-tucos (Ctenomys) from Brazilian Coastal Plains (Rodentia, Ctenomyidae). Genetica 119:11-17.

Kent JT and Mardia K (2001) Shape, Procrustes tangent projections and bilateral symmetry. Biometrika 88:469-485.

King M (1993) Species Evolution. Cambridge University Press, Cambridge, $335 \mathrm{p}$.

Klingenberg CP, Barluenga M and Meyer A (2002). Shape analysis of symmetric structures: Quantifying variation among individuals and asymmetry. Evolution 56:1909-1920.

Lessa EP and Cook JA (1998) The molecular phylogenetics of tuco-tucos (genus Ctenomys, Rodentia, Octodontidae) sug- 
gests an early burst of speciation. Mol Phylogenet Evol 9:88-99.

Lopes CM, Barba M, Boyer F, Mercier C, Silva Filho PJS, Heidtmann LM, Galiano D, Kubiak BB, Langone PQ, Garcias FM, et al. (2015) DNA metabarcoding diet analysis for species with parapatric vs sympatric distribution: A case study on subterranean rodents. Heredity 114:1-12.

Mascheretti S, Mirol PM, Giménez MD, Bidau CJ, Contreras JR and Searle JB (2000) Phylogenetics of the speciose and chromosomally variable rodent genus Ctenomys (Ctenomyidae: Octodontidae), based on mitochondrial cytochrome b sequences. Biol J Linn Soc 70:361-376.

Massarini AI and Freitas TRO (2005) Morphological and cytogenetics comparison in species of the mendocinus-group (genus Ctenomys) with emphasis in $C$. australis and $C$. flamarioni (Rodentia-ctenomyidae). Caryologia 58:21-27.

Massarini A, Barros MA and Ortells M (1991) Evolutionary biology of fossorial Ctenomyinae rodents (Caviomorpha: Octodontidae). I. Cromosomal polymorphism and small karyotypic differentiation in Central Argentinian populations of tuco-tucos. Genetica 83:131-144.

Massarini AI, Dyzenchauz FJ and Tiranti SI (1998) Geographic variation of chromosomal polymorphism in nine populations of Ctenomys azarae, tuco-tucos of the Ctenomys mendocinus group (Rodentia: Octodontidae). Hereditas 128:207-211.

Medina AI, Martí DA and Bidau CJ (2007) Subterranean rodents of the genus Ctenomys (Caviomorpha, Ctenomyidae) follow the converse to Bergmann's rule. J Biogeogr 34:1439-1454.

Mora M, Olivares AI and Vassallo AI (2003) Size, shape and structural versatility of the skull of the subterranean rodent Ctenomys (Rodentia, Caviomorpha): Functional and morphological analysis. Biol J Linn Soc 78:85-96.

Navarro A and Barton NH (2003) Chromosomal speciation and molecular divergence-accelerated evolution in rearranged chromosomes. Science 300:321-324.

Nevo E (1979) Adaptive convergence and divergence of subterranean mammals. Annu Rev Ecol Syst 10:269-308.

Novello A and Altuna C (2002) Cytogenetics and distribution of two new karyomorphs of the Ctenomys pearsoni complex (Rodentia, Octodontidae) from southern Uruguay Mammal Biol 67:188-192.

Ortells MO and Barrantes GE (1994) A study of genetic distances and variability in several species of the genus Ctenomys (Rodentia: Octodontidae) with special reference to a probable role of chromosomes in speciation. Biol J Linn Soc 53:189-208.

Ortells MO, Contreras JR and Reig OA (1990) New Ctenomys karyotypes (Rodentia, Octodontidae) from North-eastern Argentina and from Paraguay confirm the extreme multiformity of the genus. Genetica 82:189-201.

Parada A, D'Elía G, Bidau CJ and Lessa EP (2011) Species groups and the evolutionary diversification of tuco-tucos, genus Ctenomys (Rodentia: Ctenomyidae). J Mammal 92:671-682.
Paradis E, Strimmer K, Claude J, Jobb G, Open-Rhein R, Dultheil J and Bolker NB (2004) APE: Analyses of Phylogenetics and Evolution in R. Bioinformatics 20:289-290.

Reig OA, Busch C, Ortells MO and Contreras JR (1990) An overview of evolution, systematics, population and speciation in Ctenomys. In: Nevo and Reig OA (eds) Evolution of Subterranean Mammals at the Organismal and Molecular Levels. A.R. Liss, New York, pp 71-96.

Reig OA, Massarini AI, Ortels MO, Barros MA, Tiranti SI and Dyzenchauz FJ (1992) New karyotypes and C-banding patterns of the subterranean rodents of the genus Ctenomys (Caviomorpha, Ocotodontidae) from Argentina. Mammalia 56:603-623.

Rieseberg LH and Livingstone K (2003) Evolution-chromosomal speciation in primates. Science 300:267-268.

Ripley BD (1996) Pattern Recognition and Neural Networks. Cambridge University Press, Cambridge, 403 p.

Rohlf FJ and Marcus LF (1993) A revolution in morphometrics. Trends Ecol Evol 8:129-132.

Rohlf FJ and Slice D (1990) Extensions of the Procrustes method for the optimal superimposition of landmarks. Syst Zool 39:40-59.

Rohlf FJ (2004) TPSDig, version 1.40. Department of Ecology and Evolution, State University of New York, Stony Brook.

Slamovits CH, Cook JA, Lessa EP and Rossi MS (2001) Recurrent amplifications and deletions of satellite DNA accompanied chromosomal diversification in South American tucotucos (Genus Ctenomys, Rodentia: Octodontidae): A phylogenetic approach. Mol Biol Evol 18:1708-1719.

Tomasco I and Lessa EP (2007) Phylogeography of the tuco-tuco Ctenomys pearsoni: mtDNA variation and its implication for chromosomal differentiation. In: Kelt DA, Lessa EP, Salazar-Bravo JA and Patton JL (eds) The Quintessential Naturalist: Honoring the Life and Legacy of Oliver P. Pearson. University of California Publication in Zoology Series, Berkeley, pp 859-882.

Vassallo AI (1998) Functional morphology, comparative behaviour, and adaptation in two sympatric subterranean rodents genus Ctenomys (Caviomorpha: Octodontidae). J Zool 244:415-427.

Venables WN and Ripley BD (2002) MASS: Modern Applied Statistics with S. 4th edition. Springer, New York, 495 p.

Verzi DH and Olivares AI (2006) Craniomandibular joint in South American burrowing rodents (Ctenomyidae): Adaptations and constraints related to a specialized mandibular position in digging. J Zool 270:488-501.

Vitullo AD, Roldan ERS and Merani MS (1988) On the morphology of spermatozoa of tucotucos, Ctenomys (Rodentia: Ctenomyidae): New data and its implications for the evolution of the genus. J Zool 215:675-683.

\section{Supplementary material}

The following online material is available for this article: Table S1 - Definition of landmarks.

Associate Editor: Loreta B. Freitas

License information: This is an open-access article distributed under the terms of the Creative Commons Attribution License (type CC-BY), which permits unrestricted use, distribution and reproduction in any medium, provided the original article is properly cited. 